\title{
Growth, Mortality and Exploitation of Penaeus semisulcatus in Jizan Fisheries, Saudi Arabia
}

\author{
Lafi Al Solami*, and Hassan Jastinah
}

Faculty of Marine Science' King Abdulaziz University, Jeddah, Saudi Arabia

\begin{abstract}
The growth parameters, mortality coefficients and exploitation rate of Penaeus semisulcatus in Jizan fisheries were determined during the fishing season 2015 / 2016. The growth curves and parameters were estimated using length-frequency data for combined sexes (pooled data). The - growth parameters $(\mathrm{L} \infty, \mathrm{K} \& \mathrm{to})$ for the sexes combined are estimated as $\mathrm{L} \infty=94.40 \mathrm{~mm}, \mathrm{~K}=0.81$ year- $1, \mathrm{t}_{\mathrm{o}}=-0.20$ year, $\mathrm{M}=1.634$ year $^{-1}, \mathrm{Z}=3.124$ year $^{-1}$, and $\mathrm{F}=1.961$ year $^{-1}$. The results indicated that, the current exploitation rate 'Ecur $=0.628$ ' was higher than that required to get the maximum sustainable yield per recruit $' \mathrm{E}_{\max }=0.581$.In the present study $\mathrm{B} / \mathrm{R}$ was found $5.98 \mathrm{gm}$. The current biomass per recruit ratio indicates that the current exploitation rate is not suitable for maintaining a sufficient spawning stock biomass of $P$. semisulcatus in Jizan area which indicates that the stock status of fisheries is currently overexploited.
\end{abstract}

Keywords: Red Sea, Penaeus semisulcatus, growth, mortality, fisheries. Jizan.

\section{Introduction}

Six shrimp species were recorded in the commercial landings of Jizan region (Abdallah and Abushusha 2003, PERSGA/GEF. 2002). The green tiger shrimp Peneaus semisulcatus is the most dominant species constituting between $85-90 \%$ of the commercial catches taken by bottom trawlers operated in the Red Sea coast of Saudi Arabia (Abdallah \& Abushusha, 2003). Due to the highest market value, the Red Sea fishing fleet targets mainly $P$. semisulcatus. This species is widely distributed in the Indo-Pacific region (Holthuis, 1980), and is fished commercially from Southeast coast of India to the Arabian Gulf and the Red Sea. In the Red Sea waters, the distribution of $P$. semisulcatus is associated with the extension of the continental shelf where the bottom is muddy, especially in three regions; Jizan area in the south, Al-Qunfedah area, and in Al-Khoribah area in the far north. The Jizan region is by far the most important fishing ground where more than $90 \%$ of the shrimp trawlers operate (Abdallah and Abu-Shoushah 2003).

However, limited data are available on $P$. semisulcatus in the Red Sea indicated that the stock of the green tiger prawn fishery in the Jizan was overexploited during the fishing season 2000. Therefore, this study aims mainly to assess the fishery status of $P$. semisulcatus in Jizan fisheries (Ghamrawy, 1988, 1990; Abdallah and Abushusha, 2003). Previous work carried out by Abdallah and Abushusha (2003).

\section{Materials and Methods}

\section{Sampling:}

Samples were collected twice monthly (first and third week of the month) from the landed 
catch of shrimp trawlers at Jizan landing site during the study period (Aug 2015-Mar 2016). Shrimp species were identified according to FAO species identification sheets, for shrimp trawl catch (Fischer and Blanchiceds, 1984). Species composition of the commercial landing of shrimp trawl in Jizan region was determined and the samples of $P$. semisulcatus were separated to take the different measurements (Figs.1-2). Females and males were determined. For all individuals, Vernier calipers were used to measure lengths to the nearest $0.1 \mathrm{~mm}$, and weight measurements were recorded using a digital balance having a sensitivity of $0.01 \mathrm{~g}$.

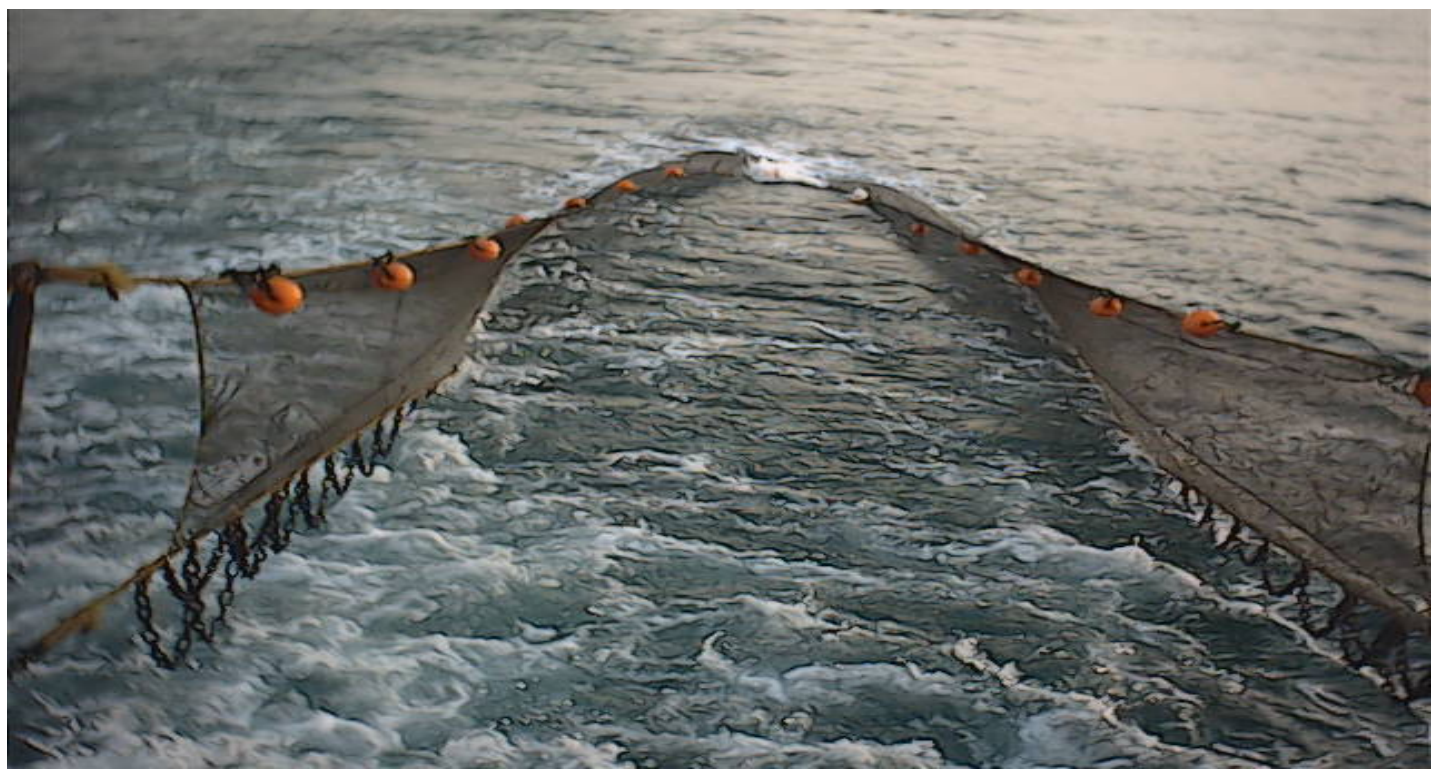

Fig. 1. The trawl fishing in Jizan area.

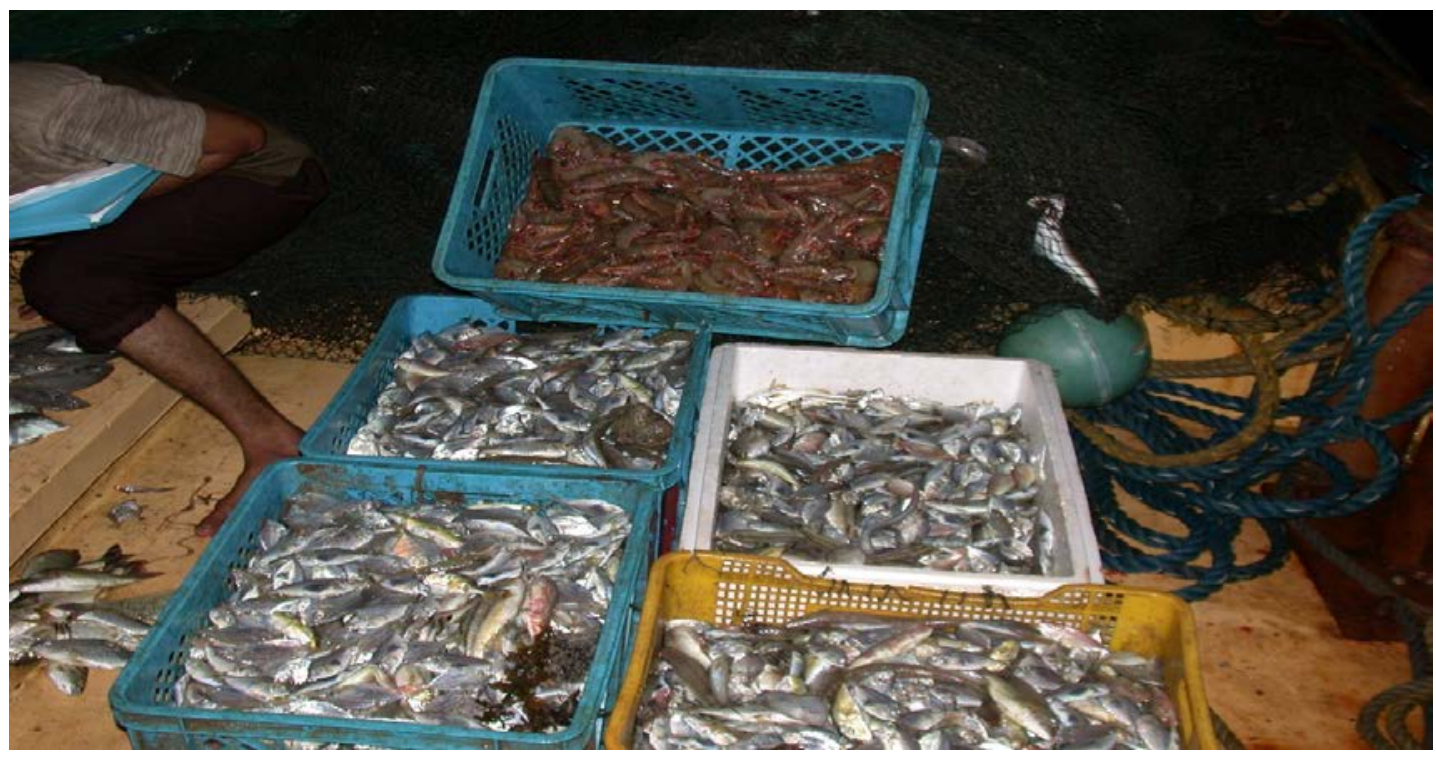

Fig. 2. The catch of trawl net in Jizan area. 


\section{Data Analysis}

The FiSAT II software was used to estimate growth parameters through the analysis of length-frequency of $P$. semisulcatus. The maximum theoretical length $\mathrm{L} \infty$, growth coefficient $\mathrm{K}$, growth amplitude $\mathrm{C}$, and winter point WP were estimated in the ELEFAN I routine (Pauly and David 1981). The instantaneous total mortality coefficient (Z) was estimated using Jones and van Zalinge (1981) plot implemented in the ELEFAN II routines of the FiSAT II Package. The coefficient of natural mortality (M) was estimated by the method of Pauly (1980) considering the mean annual temperature as $28^{\circ} \mathrm{C}$ (Morcos, 1970). The Fishing mortality coefficient (F) was considered as the difference between $\mathrm{Z}$ and $\mathrm{M}$.

Carapace length at first capture $\left(\mathrm{L}_{50}\right)$ was estimated using the plot of probability of capture by length (Pauly, 1984). Total length at first capture was derived from the estimated carapace length according to Pauly and Soriano, (1986). ELEFAN II program was used to calculate the relative yield-per-recruit $\left(\mathrm{Y}^{\prime} / \mathrm{R}\right)$ and biomass-perrecruit $\left(\mathrm{B}^{\prime} / \mathrm{R}\right)$.

$$
\begin{gathered}
\text { "Y'/R" }=\mathrm{E} \mathrm{U} \mathrm{M} / \mathrm{K}[1-(3 \mathrm{U} /(1+\mathrm{m}))+ \\
(3 \mathrm{U} 2 /(1+2 \mathrm{~m}))-(\mathrm{U} 3 /(1+3 \mathrm{~m})) .
\end{gathered}
$$

Where: $\quad \mathrm{m}=\mathrm{K} / \mathrm{Z}=\left(\frac{1-E}{M / K}\right)$

$$
\mathrm{U}=1-(\mathrm{Lc} / \mathrm{L} \infty) \quad \mathrm{E}=\mathrm{F} / \mathrm{Z}
$$

$\mathrm{K}=$ von Bertalanffy growth parameter.

$\mathrm{Z}=$ Total mortality coefficient.

$\mathrm{F}=$ Fishing mortality coefficient.

$\mathrm{L} \infty=$ von Bertalanffy constant

'Lc', the length at first capture, the length at which all fish of that length and longer are under full recruitment.

The relative biomass per recruit was computed as:

$$
\text { "B'/R" ="Y'/R" / F. }
$$

The exploitation ratios E10, E50 and Emax were determined by using FiSAT software program.

\section{Results}

\section{Growth Parameters}

The restructured carapace length frequency of $P$. semisulcatus is shown in Figure (3), with superimposed growth curves. The monthly length frequency distributions were analyzed by ELEFAN program (Pauly and David 1981) incorporated in LFDA software for the estimation of growth parameters $\left(\mathrm{L}_{\infty}, \mathrm{K}\right.$ $\& t_{0}$ ) for the sexes combined. Where $L_{\infty}$ is the asymptotic total length, $K$ is the curvature parameter and $t_{0}$ is the Age at length zero. They are estimated as $\mathrm{L}_{\infty}=$ $94.40 \mathrm{~mm}, \mathrm{t}_{\max }=3.70$ year, $\mathrm{K}=0.81$ year1 and $\mathrm{t}_{0}=-0.20$ year. 
Growth Curve $=$ Pauly Seasonal. Linf $=94.40 . K=0.81$. Tzero $=-0.20$.

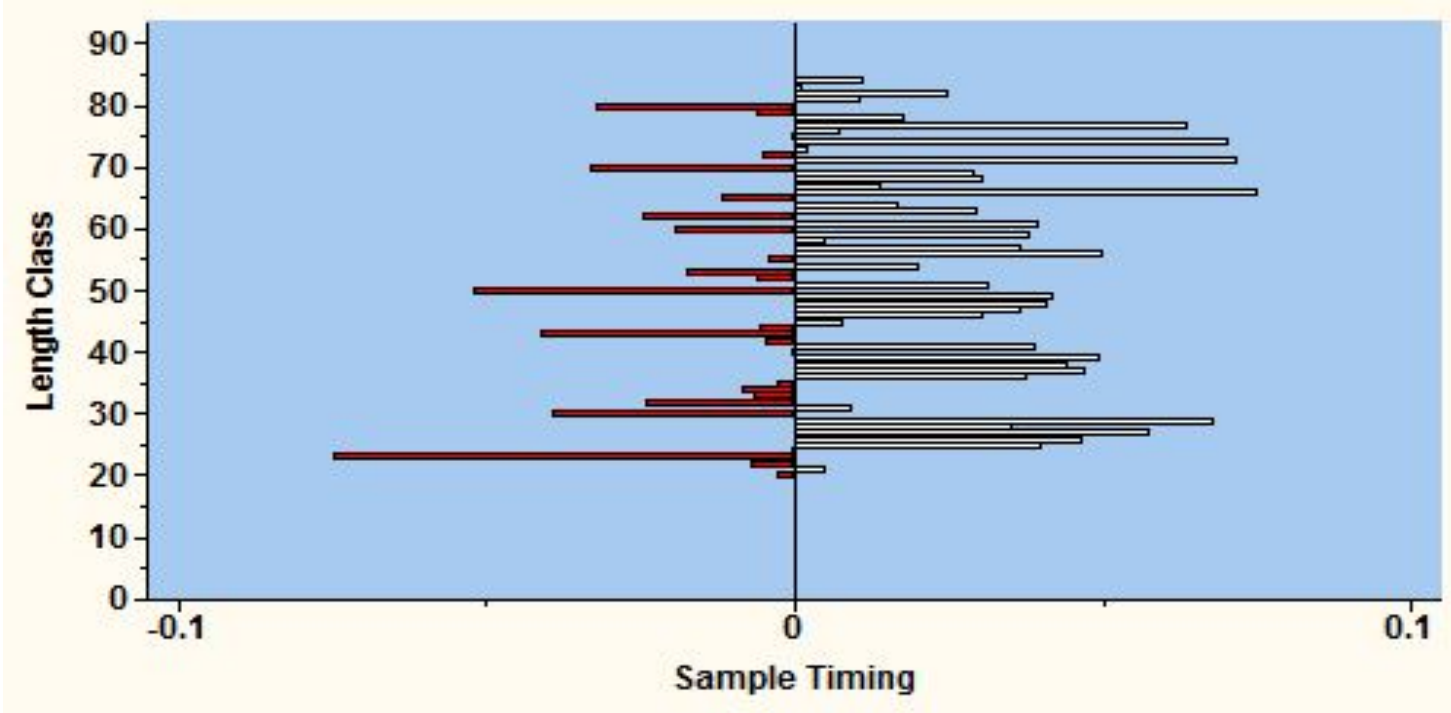

Fig. 3. Growth parameters $\left(\mathrm{L}_{\infty}, \mathrm{K} \& \mathrm{t}_{0}\right)$ of $P$. semisulcatus in Jizan area (output of the LFDA software).

\section{Mortalities rates:}

Fishing mortality coefficient was calculated as a result of subtraction of $\mathrm{M}=1.163$ year $^{-1}$, $\mathrm{F}=1.961$ year $^{-1}$, and $\mathrm{Z}=3.124$ year $^{-1}$ from
(Beverton and Holt, 1957). This was found to be 1.961 year $^{-1}$.

Jones and van Zalinge Plot

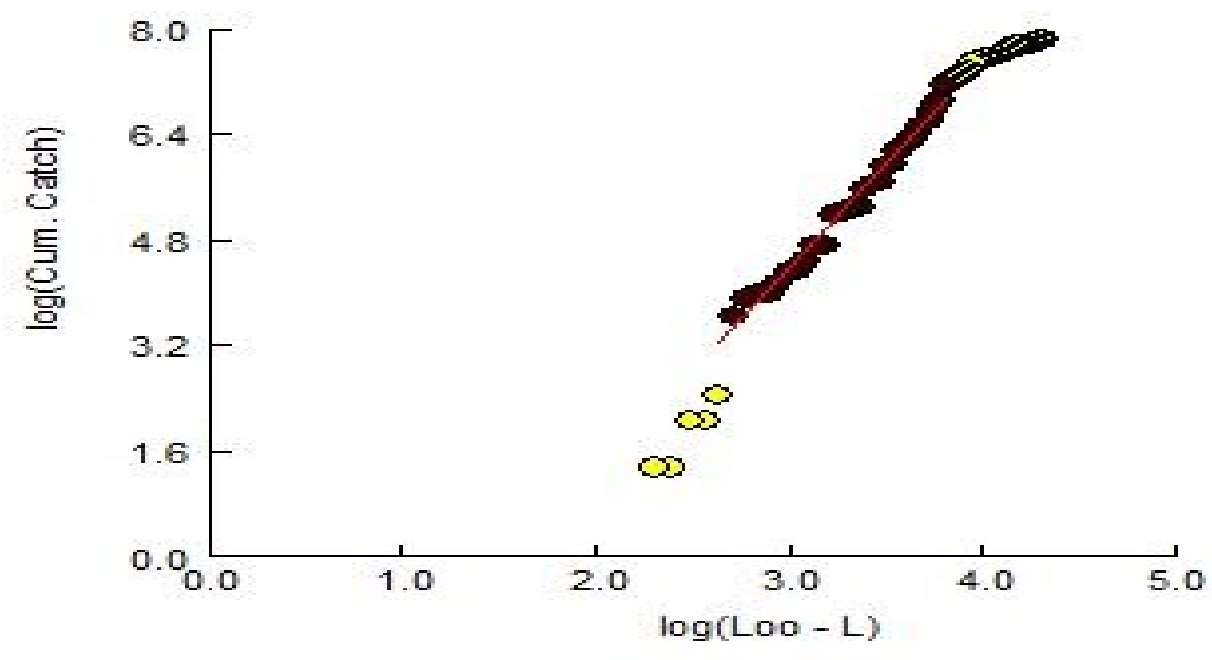

Fig. 4. Jones and van Zalinge plot for P. semisulcatus. 
Carapace length and age at first capture:

The corresponding age at first capture "tc" was calculated by the following equation (Beverton \& Holt, 1957):

tc $=(-1 / \mathrm{K})(\ln ((1-\mathrm{Lc} / \mathrm{L} \infty)+$ to $)$

Where " $K, L \infty \&$ to" are the Von Bertalanffy constants and "Lc" is the length at first capture.

The carapace length at first capture $\mathrm{L}_{50}$ (the carapace length at which $50 \%$ of individuals at that size are vulnerable to capture) was estimated as $35.73 \mathrm{~mm}$ for combined sexes, and the corresponding age at first capture $\left(\mathrm{t}_{\mathrm{c}}\right)$ was 0.387 year.

Relative yield / recruit (Y'/R), relative biomass / recruit (B'/R)

The plot of relative yield per recruit " $\mathrm{Y} / \mathrm{R}$ " and relative biomass per recruit "B'/R" of $P$. semisulcatus in Jizan fisheries against the exploitation rate “E” are graphically represented in fig. (5) and tabl ( 1 ).

The yield-based biological reference points E10 (the exploitation rate at which the marginal increase of $Y^{\prime} / R$ is $1 / 10$ of its value at $E=0$ ), E-50 (the exploitation rate under which the stock has been reduced to $50 \%$ of its unexploited biomass), and E-max (the exploitation rate which produces maximum yield per recruit) of exploitation rates were found to be $\mathrm{E}-10=0.502$, E-50=0.328 and E$\max =0.581$ year-1. The current level of exploitation E-cur was estimated to be 0.628 year-1, and both E-10 and E-max are lower than the current exploitation rate.

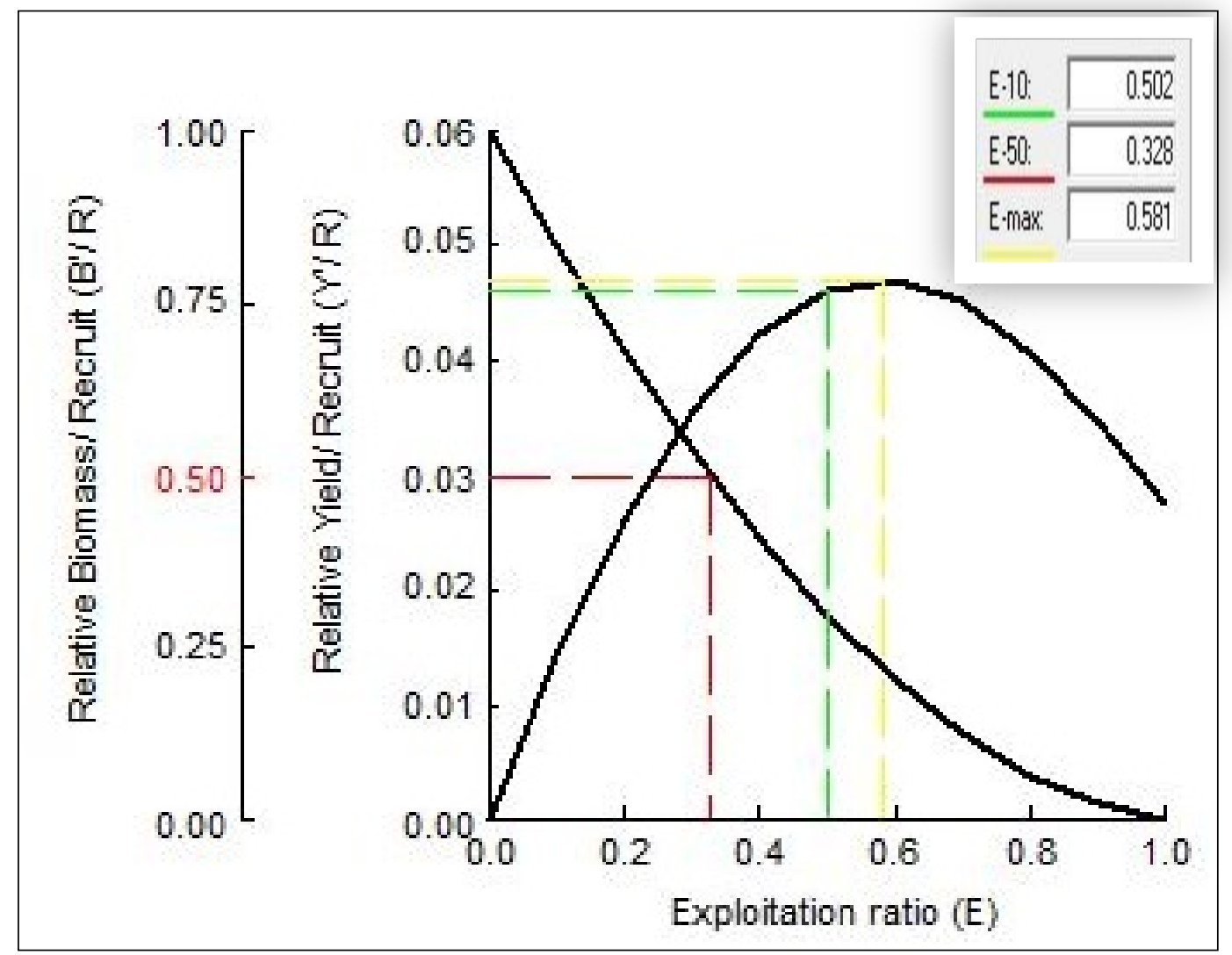

Fig. 5. Relative yield / recruit ( $\left.Y^{\prime} / \mathrm{R}\right)$, and relative biomass / recruit (B'/R) for $P$. semisulcatus in Jizan fisheries. 
Table 1. Yield / recruit and average biomass / recruit of $\boldsymbol{P}$. semisulcatus as a function of fishing mortality.

\begin{tabular}{|c|c|c|c|}
\hline $\mathbf{F}$ & $\mathbf{Y} / \mathbf{R}$ & $\mathbf{B} / \mathbf{R}$ & \% Bv \\
\hline 0.000 & 0.0000 & 33.477 & 100.00 \\
\hline $0.845(0.1)$ & 10.8808 & 12.880 & 38.46 \\
\hline 1.000 & 11.2999 & 11.300 & 33.75 \\
\hline 1.200 & 11.6149 & 9.680 & 28.91 \\
\hline 1.601 & 11.8040 & 7.373 & 22.02 \\
\hline 1.607 (max) & 11.8041 & 7.345 & 21.94 \\
\hline 1.612 & 11.8040 & 7.323 & 21.87 \\
\hline 1.800 & 11.7770 & 6.543 & 19.54 \\
\hline $1.961(\mathrm{cur})$ & 11.7230 & 5.979 & 17.86 \\
\hline 2.500 & 11.4340 & 4.574 & 13.66 \\
\hline 3.000 & 11.1160 & 3.705 & 11.07 \\
\hline
\end{tabular}

\section{Discussion}

Due to the developing technology and fishing equipment, the fishing effort exerted on fishery resources has been increasingly modified leading to overfishing problems which may result in reducing fish stocks to biologically and ecologically harmful levels. Investigating the population dynamics such as age, growth and mortalities are very important to assess the current status of any given population.

In the present study, the asymptotic total length for combined sexes $\left(L_{\infty}=94.4 \mathrm{~mm}\right)$; was higher than those estimated _ in previous study reported by Hussain et. al. (1996) in Jizan area for females and males, respectively (54.3mm and $37.0 \mathrm{~mm}$ during the fishing season 1985/1986; $49.5 \mathrm{~mm}$ and $36.1 \mathrm{~mm}$ during $1986 / 1987 ; 52.1 \mathrm{~mm}$ and $36.8 \mathrm{~mm}$ during $1987 / 1988 ; 50.9 \mathrm{~mm}$ and $37.1 \mathrm{~mm}$ during $1988 / 1989$, and $49.0 \mathrm{~mm}$ and $36.1 \mathrm{~mm}$ during 1989/1990).
The above mentioned different values of asymptotic carapace lengths for females and males may be attributed to the excess fishing effort exerted by trawling on the stock of this species in Jizan fisheries. In the present study, the growth coefficient "K" of $P$. semisulcatus in Jizan area during the fishing season 2015/2016 was found to be 0.81 . Hotzhausen and Kirchner (2001) reported that as the value of " $K$ " increases the rate of growth increases. This would explain the higher growth rate of P. semisulcatus. Abdul-Wahab (2014) studied the population dynamics of $P$. semisulcatus in the Yemeni Red Sea water, and found that the current exploitation rate, $\mathrm{E}$, is the best compromise resulting in higher stock biomass and higher catch rate than that obtained at $E_{\max }$ and $E_{0.1}$. In the present study, results of the relative yield per recruit $\left(\mathrm{Y}^{\prime} / \mathrm{R}\right)$ indicated that the current exploitation rate is higher than $E_{\max }$ which generates the maximum yield per recruit. In addition, the current values of " $E$ " are higher than the values of " $E_{0.5}$ " which consider the exploitation level that maintains 
the spawning stock biomass at $50 \%$ of the virgin spawning stock biomass for the species under study. The current biomass per recruit ratio indicates that the current exploitation rate is not suitable for maintaining a sufficient spawning stock biomass of $P$. semisulcatus in Jizan area. Conclusion, Based on that, this study recommended the eduction of exploitation rate from $\mathrm{E}_{\text {- }}{ }_{\text {ur }}=0.628$ to $\mathrm{E}_{-10}=$ $0.502 \mathrm{yr}^{-1}$ and further monitoring and management through estimation of the optimal exploitation rates, female spawner relative stock biomass as targeted reference points.

\section{References}

Abdul-Wahab, M. M. (2014) Population dynamics of the shrimp Penaeus semisulcatus in the Yemeni Red Sea waters. Iranian Journal of Fisheries Sciences, 13 (3): 585596.

Beverton, R.J.H. and Holt, S.J. (1957) On the dynamics of exploited fish populations. Fish. Invest. Ser. 2, Mar. Fish. GB Minist, Agric. Fish. Food, (Great Britain), 19, 533.

Beverton, R.J.H. and S.J. Holt( 1966) Manual of methods for fish stock assessment. Part II. Tables of yield function. FAO Fish. Biol. Tech. Pap., (38) $10+67$ pp. (ver. 1).

Fischer, W. and Blanchiceds, G. (1984) FAO species identification sheets for Fishery purposes. Western Indian Ocean (Fishing Area 51). Prepared and printed with the support of the Danish International Development Agency (DANIDA), Rome, Food and Agriculture Organization of the United Nation, Vol (6).

Gayanilo, F. C. Jr., Sparre, P. and Pauly, D. (1995) FAOICLARM Stock assessment tools (FiSAT) user's manual. FAO Comp. Info. Ser. (Fisheries) 8. 126p.

Ghamrawy, M. S.(1988). Some penaeid shrimp species from the Red Sea and the Arabian Gulf, Arab. Gulf J. Scient. Res. Agri. Biol. Sci., B (6): 113-128.

Ghamrawy, M. S.(1990). Notes on the Biology of penaeid shrimp at Gizan, Red Sea, J. K. A. U. Mar. Sci., 1: $67-76$.

Holtzhausen, J.A. and Kirchner, C.H. (2001) Age and growth of two populations of West Coast Steenbras
Lithognathus aureti in Namibian waters, based on otolith readings and mark-recapture data. In A decade of Namibian Fisheries Science. Payne, A. I. L, Pillar, S. C. and R. J. M. Crawford (Eds), S. Afr. J. Mar. Sci., 23: 169-179.

Hussain, M. A. M., James, M. B. and Xucai, X. (1996) Population characteristics of green tiger prawns, Penaeus semisulcatus, in Kwait waters perior to the Gulf War. Hydrobiologia, 337: 37-47.

Jones, R. and N.P. van Zalinge (1981) Estimations of mortality rate and population size for shrimp in Kuwait waters, Kuwait Bull. Mar. Sci., 2: 273-288.

Mohamed, A. and Abushusha, T. L. (2003) Population dynamics and sustainable exploitation of green tiger shrimp Penaeus semisulcatus in the Jizan area (Southern region of the Saudi Arabian Red Sea coast), J. Egypt. Acad. Soc. Environ. Develop., (D- Environmental Studies) 4, (2): 65-87.

Morcos, S. A. (1970) Physical, chemical and oceanography of the Red Sea, Oceanog. Mar. Biol. Ann. Rev., (8): 73-202.

Pauly, D. and David, N. (1981) ELEFAN I, a BASIC program for the objective extraction of growth parameters from length-frequencies data. Meeresforsch., 28 (4): 205211.

Pauly, D. and Soriano, M. L. (1986) Some practical extensions to Beverton and Holt's relative yield-perrecruit model, pp: 491-6. In Maclean, J. L., Dizon, L. B. and Hosillo, L. V. (eds.) The first Asian Fisheries Forum. Asian Fisheries Siciety, Manila, Philippines.

Pauly, D. (1980) On the interrelationships between natural mortality, growth parameters and mean environmental temperature in 175 fish stocks, J. Cons. CIEM, 39, (3): 175-192.

Pauly, D. (1984) Length-converted catch curves: a powerful tool for fisheries research in the tropics (Part II), ICLARM Fishbyte, 2, (1): 17-19.

Pauly, D. (1986) On improving operation and use of the ELEFAN programs. Part II. Improving the estimation of Lo, ICLARM Fishbyte, 4, (1): 18-20.

PERSGA/GEF (2002) Status of the Living Marine Resources in the Red Sea and Gulf of Aden. PERSGA, Jeddah and The World Bank, Washington, D.C. 134 p. 


\section{النمو و النفوق و الاستغلال لمصايد روبيان أم نعيرة (بينيوس سميسلكيتس) في مصايد جيزان، المملكة العربية السعودية العين العين}

\section{لافي السلمي، وحسن جستينية}

\section{كلية علوم البحار، جامعة الدلك عبدالعزيز، جدة، الدملكة العربية السعودية}

المستخلص. تناولت هذه الدراسة تحديد معدلات النفوق والنمو والإنتاج لمصائد الروبيان أم نعيرة

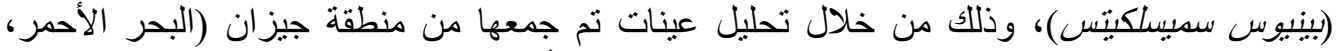

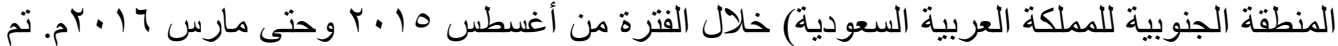

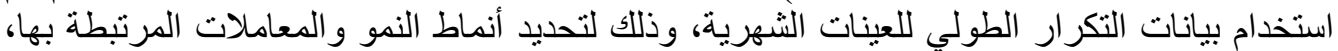

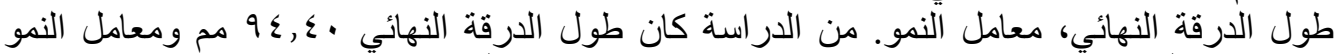

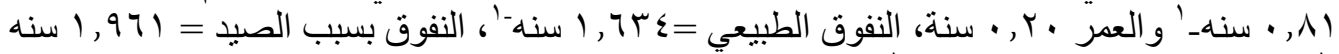

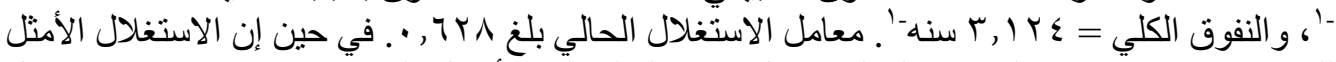

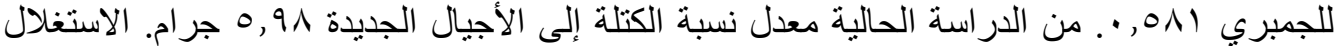

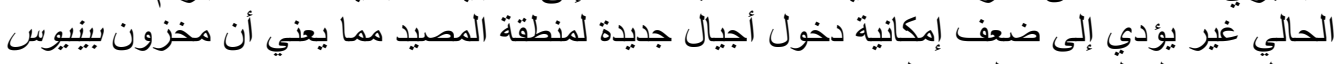
سميسلكيتس الحالي تحت الصيد الصيد الجائر. الكلمات الدالة: روبيان أم نعيرة، بينيوس سميسلكيتس، النمو، الفقد، المصائد، جيزان، البحر الأحمر. 